\title{
Yeni Osmanlıcılığa İdeolojik Destek Mi, Türk Modernleşmesinin Kapsamlı Çözümleme Çabası Mı? Kemal H. Karpat'ın Tarih Yazıcılığı
}

\section{Ideological Support for Neo-Ottomanism or Comprehensive Analysis of Turkish Modernization? The Historiography of Kemal H. Karpat}

\author{
Fahri YETIM* (i)
}

*Prof. Dr., Eskişehir Osmangazi Üniversitesi, Fen-Edebiyat Fakültesi Tarih Bölümü, Eskişehir, Türkiye

ORCID: F.Y. 0000-0001-9921-3193

Sorumlu yazar/Corresponding author: Fahri Yetim,

Eskişehir Osmangazi Üniversitesi, Fen-Edebiyat Fakültesi Tarih Bölümü, Eskişehir, Türkiye

E-posta/E-mail: fyetim@ogu.edu.tr

Başvuru/Submitted: 16.03.2021 Revizyon Talebi/Revision Requested: 08.04.2021

Son Revizyon/Last Revision Received: 03.05.2021

Kabul/Accepted: 03.05.2021

Atıf/Citation: Yetim, Fahri. "Yeni Osmanlıcılığa İdeolojik Destek Mi, Türk Modernleşmesinin Kapsamlı Çözümleme Çabası Mı? Kemal H. Karpat'ın Tarih Yazıcılığı." Yakın Dönem Türkiye AraştırmalarıRecent Period Turkish Studies 39 (2021): 289-302.

https://doi.org/10.26650/YTA2021-897663
ÖZ

Olgulardan hareketle olaylar arasındaki neden-sonuç ilişkisini göz önünde bulundurarak tarihsel geçmişi ve toplumsal gerçekliği açıklamaya çalışan tarih, kendine özgü metodolojik özelliklerinin yanında, bir ölçüde tarihçinin bakış açısına göre şekillenen bir bilimdir. Esasen sosyal bilimlerin geneli için de söz konusu olan bu durum, nesnellik konusunu gündeme getirmekle beraber, verilerin toplanması ve değerlendirilmesinde tarihçinin başat konumu dolayısıyla kaçınılmaz görünür. Türkiye'nin önde gelen tarihçilerinden olan Kemal H. Karpat, Türk modernleşmesini zengin birikimi ve disiplinler arası bir bakış açısıyla ele alarak kapsamlı bir şekilde çözümlemeye çalışmıştır.

Bu çalışma esas itibarıyla, Karpat'ın tarihçiliği konusunda yukarıda bahsedilen indirgeyici bakış açılarının bir örneği olan Nuray Sancar'ın, söz konusu tarihçi ile ilgili eleştirel yaklaşımlarına bir cevap mahiyeti taşımaktadır.

Anahtar Kelimeler: Kemal Karpat, Türk Modernleşmesi, Yeni Osmanlıcılık, İslam'ın Siyasallaşması

\section{ABSTRACT}

History, as an academic field, seeks to explain past and present social circumstances by using facts to consider the causal relationship between events. In addition to having unique methodological features, history is shaped in part by the historian's own point of view. This situation, which extends to the social sciences in general, raises the issue of objectivity, but seems inevitable given the dominant position of the historian in collecting and evaluating data.. Kemal H. Karpat, one of the most prominent historians of Turkey, has tried to analyze Turkish modernization in a comprehensive way by considering it with a rich background and an interdisciplinary perspective. This study is essentially a 
response to Nuray Sancar's critical approaches to the historian in question, which are exemplary of the reductionist perspectives typically applied to Karpat's historiography.

Keywords: Kemal Karpat, Turkish Modernization, Neo-Ottomanism, Politicization of Islam

\section{Extended Abstract}

History, which has an important place in the social sciences, is a discipline that seeks to explain social change by incorporating data in an optimal way based on its own methodological principles. However, the results obtained are generally shaped by the perspective of the particular historian who studies a given topic. This is especially the case in modern historiography. While historical problems at all scales can be examined by incorporating multidisciplinary approaches to history in an interdisciplinary framework, the methodological richness and basic perspective of the historian come to the fore as determining factors. Again, versatile and consistent perspectives are needed to assess this inevitable situation reasonably. Modern historiography, which has a history of about two centuries, is now expected to reveal and examine issues that have been addressed from all perspectives. This field, which can also be described as intellectual historiography, naturally demands very special training and skills. Examples of this kind of historiography in the world are very limited. In the case of Turkish historiography in particular, whether addressing philological problems or issues at instrumental level, there are a wide range of handicaps, from extent of interdisciplinary approach to depth of judgment. Even when all such problems can be overcome, the findings thus obtained may remain unsatisfying in terms of historiography.

The historian Kemal H. Karpat was subjected to the assassination of silence in the field of historiography, like Ahmet Hamdi Tanpınar and Oğuz Atay in the literary world and Kemal Tahir in the intellectual world, and systematically ignored. This negligence continued even after his death. With the exception of a gift made during his lifetime, no study of his historiography has been published. His death has also been quietly avoided, apart from one or two articles. Therefore, Karpat is an intellectual whose work merits additional attention. As a matter of fact, this issue belatedly caught the attention of the academy, and two studies were conducted on the subject before the death of Karpat. One of these studies was conducted by Lütfi Sunar, who argued that Karpat remained far outside mainstream social science in Turkey. This was mainly because, at a time when document-based historiography was in demand, Karpat generally preferred a social history perspective, which only later became popular and widespread. 
In this sense, Karpat, as one of the leading historians of Turkey, produced important work in this area. Karpat was one of the greats among the latest generation of Turkey's historians, undertaking highly sophisticated studies in political history, including the Ottoman and Republican periods, in economic history, and particularly in the social history of culture and intellectual life. Karpat made a significant contribution to understanding modern Turkey's history in a comprehensive way, rather than simply providing another viewpoint on the history of Turkey's modernization. It is quite regrettable in terms of historical understanding and historiography that Karpat's work, the result of considerable labor as in every field of working life, has been coopted in contemporary speculations on Neo-Ottomanism and Moderate Islam. History, which tries to reveal the past of a given human community in a comprehensive way, must ultimately help to shed light on matters as they are today. 


\section{Giriş}

Sosyal bilimler içinde önemli bir yeri olan tarih, kendi yöntemsel ilkelerinden hareketle toplumsal değişimi, verileri optimal bir şekilde işin içine katarak açıklamaya çalışan bir disiplindir. Böyle olmakla beraber elde edilen sonuçlar genellikle bu alanda kalem oynatan tarihçinin sahip olduğu formasyona göre şekillenir. Özellikle günümüz tarihçiliği açısından bu durum fazlasıyla böyledir. Makro düzeydeki sorunlardan mikro ölçekteki konulara kadar tarihsel açıdan problem olarak ele alınan konular, tarihin disiplinler arası çok yönlü yaklaşımlarına tabi tutularak incelenirken, varılan sonuçların değerlendirilmesinde tarihçinin sahip olduğu metodolojik zenginlik ve bu doğrultuda geliştirdiği temel perspektif belirleyici olarak ön plana çıkar. Bu kaçınılmaz durumun makul bir şekilde değerlendirilmesi için yine çok yönlü ve tutarlı bakış açılarına ihtiyaç vardır. Yaklaşık iki asırlık bir geçmişi olan modern tarihçiliğin günümüzde geldiği aşamada, olgular ekseninde ele alınan konuların tüm boyutlarıyla ortaya konulması ve irdelenmesi tarihçilikten beklenen bir durum olarak karşımıza çıkar. Entelektüel tarihçilik olarak da nitelendirilebilecek olan bu alan, doğal olarak çok özel donanım ve beceri gerektiren bir durumdur. Bu tür tarihçiliğin dünyadaki örnekleri çok sınırlıdır. Özellikle Türk tarihçiliği açısından bakıldığında filolojik sorunlardan, aletsel düzeydeki diğer hususlara; disiplinler arası yaklaşım düzeyinden derin bir muhakeme gücüne kadar geniş bir handikap alanı söz konusudur. Bütün bu sorunların aşılabildiği durumlarda dahi tarihçilik açısından elde edilecek bulgular muhatabını tatmin edebilecek düzeyde olmayabilir.

Türkiye' nin son nesil büyük tarihçileri arasında yer alan Kemal Karpat için de böyle bir durum söz konudur. Doğduğu yer ve zamandan, geçirdiği akademik kariyeri ve hayat tecrübesine kadar büyük tarihçiliğin seçkin örnekliğini sergileyen Karpat, son derece yetkin bir metodolojik yaklaşımla gerçekleştirdiği çalışmalarla Türkiye'nin modernleşme serüvenini kapsamlı bir şekilde açıklamaya çalışmıştır. İki yıl önce 95 yaşında vefat eden Karpat, uzun yaşamı boyunca (son dönemler hariç) mesleki olarak Türkiye'de hak ettiği ilgiyi görmemiştir. Buna ilaveten yaklaşık üç çeyrek asra varan çalışmalarından ortaya çıkan külliyatı, bazı ideolojik değerlendirmelere kurban edilmek tehlikesiyle karşı karşıya bırakılmıştır.

\section{Göz Ardı Edilen Tarihçi}

Kemal Karpat, tarihçilik alanında tıpkı edebiyat dünyasında Ahmet Hamdi Tanpınar, Oğuz Atay, düşünce dünyasında Kemal Tahir örneklerinde olduğu gibi sükût suikastine maruz kalmış, sistematik olarak göz ardı edilmiş bir tarihçidir. Hatta bu ihmal, 
ölümünden sonra da devam etmiştir. Hayattayken kendisi için çıkarılan "Karpat'sız" bir $\operatorname{armağan}^{1}$ dışında tarihçiliğine dair çalışma yapılmamıştır. Ölümü de bir-iki yazı dışında sessizce geçiştirilmiştir. Dolayısıyla Karpat, salt bu yönüyle de ele alınması gereken entelektüellerden biridir. Nitekim bu husus akademinin geç de olsa dikkatini çekmiş, Karpat'ın ölümünden önce bu konuyla ilgili iki çalışma kaleme alınmıştır. Bu çalışmalardan biri Lütfi Sunar tarafindan kaleme alınmıştır². Lütfi Sunar'ın bu konuyla ilgili temel tespitlerinden birine göre Karpat, Türkiye'deki ana akım sosyal bilim ve ana akım tarihçiliğin uzağında kalmıştır. Bunun da başlıca nedeni, belge tarihçiliğinin revaçta olduğu zamanlarda Karpat, çoğunlukla daha sonra popüler ve yaygın hale gelecek olan sosyal tarih perspektifini çalışmalarına dâhil etmiş olmasıdır. Türkiye'de tarihçilerin halen mesafeli oldukları sosyal problemleri çözümleme ve aşağıdan bir bakış açısıyla tarihi yeniden yazma yöntemi Karpat'ın erken dönemlerden itibaren denediği bir yöntem olup, halen hâkim tarihçiliğin, tarihçilikten kopma olarak gördüğü bir durumdur. Türkiye'de özellikle sosyal bilimlerde fazlasıyla görülen disiplinlerarası yaklaşım eksikliği Karpat'ın çalışmalarının dikkat çekmemesinin temel sebeplerinden biridir³

Karpat'ın sözünü ettiğimiz yöntemle geliştirdiği tarih perspektifi, Türkiye'de demokrasinin gelişim seyriyle ilgili farklı bakış açılarına da 1şık tutmaktadır. Türk siyasal sistemi ve bunun besleyicisi konumundaki hakim entelektüel yapı tarafindan içselleştirilmiş zihniyete göre Türkiye'de demokratikleşmenin önündeki engeller ve başlica handikap unsurlarının bu tür bir yöntemle ortaya konulması ve irdelenmesi çok da benimsenen bir durum değildir. Dolayısıyla Karpat'ın göz ardı edilmesinin asıl nedenlerinden birini de burada aramak gerekir. Bu durumu Murat Belge'nin, “...belki de aydinların istemediği bir şeydir, belki de aydınların kendileri de demokrasi azlığının nedenlerinden biridir" ${ }^{4}$ şeklindeki sözlerindeki espri bağlamında ele alındığında bu durumun pek çok şeyi açıklayıcı yönleri olduğu görülür.

1 Denize Kavuşan Irmak, Ed. Kaan Durukan ve diğerleri, İstanbul, Timaş Yayınları, 2020.

2 Bunlardan bir diğeri de tarafımızdan yazılan “Türkiye'nin Modernleşme Tarihçisi Kemal Karpat” adlı kitap bölümüdür. Fahri Yetim, "Türkiye'nin Modernleşme Tarihçisi Kemal H. Karpat”, Yaşayan Türk Tarihçileri, Ed. Ahmet Şimşek, Ankara, Pegem Akademi, 2018.

3 Lütfi Sunar, "Karpat Neden Göz Ardı Edildi? Modernleşmeye Dair Farklı Bir Bakış”, Tezkire, S. 64 (Nisan-MayısHaziran 2018), s. 33.

4 Murat Belge, “Osmanlı'da ve Rusya'da Aydınlar”, Türk Aydını ve Kimlik Sorunu, Yay. Haz. Sabahattin Şen, İstanbul, Bağlam Yayınları, 1995, s. 132. 


\section{Kemal Karpat'a Yönelik Eleştirel Görüşler ve Değerlendirmelerimiz}

Karpat'la ilgili yazılan metinlerden biri de 2009 y1lında Nuray Sancar ${ }^{5}$ tarafindan kaleme alınmış olup, onun tarihçiliğini sosyalist bakış açısıyla ele alan eleştirel bir makaledir ${ }^{6}$. Bu çalışmanın konusunu da adı geçen makaledeki eleştiriler ve bunlara ilişkin değerlendirmeler oluşturmaktadır.

Yazarın, Karpat'ın tarihçiliğiyle ilgili ilk tespitlerinden biri olan ve "Karpat'ın çalışmalarındaki temel yaklaşımı teşkil eden tarihsel sürekliliği ön plana çıkarması, kırılmaları önemsizleştirmesi, Türk modernleşmesinde; III. Selim'le başlayan ve Abdülhamid'le ivme kazanan reformların Cumhuriyet' in temellerini oluşturduğuna inanması ve modernleşmede İslam'ın ideolojik etkisini birinci derece önemsemesi... gibi durumların; resmi tarih anlayışına objektif bir bakış açısıyla bakan tarihçileri (kimleri kast ediyor?) ve politikacıları rahatsız etmiş" "̧ şeklindeki görüşleridir. Bu konuyla ilgili olarak öncelikle, Türkiye'de resmi tarih anlayışına Karpat düzeyinde objektif bakış açısına sahip tarihçilik durumunun son derecede sınırlı olduğunun belirtilmesi gerekir. Karpat, tarihsel sosyolojik yaklaşımdan hareket ederek resmi tarihi Türk modernleşmesinin bütünlüğü içinde ele almış ve bu konuda objektifliğin en iyi örnekliğini sergilemiştir. Karpat'ın çalışmalarında "rahatsız edici" unsurlar olarak sıralanan hususlar, bugün Türk modernleşmesiyle ilgili üst düzey tarihçilerin (Carter V. Findley, Stanford J. Shaw, Halil İnalcık, İlber Ortaylı, Engin Deniz Akarlı...) mutabakatla kabul ettiği gerçeklikler arasında yer alır. Bu durumda rahatsızlık (varsa eğer) ancak müktesebat konusunda Karpat'ın zenginliğinden ortaya çıkabilecek farktan kaynaklanıyor olabilir. Bundan dolayı objektif yaklaşım konusunda makale yazarının bu yöndeki tespitlerine katılmak mümkün görünmemektedir.

Diğer bir husus olan yazarın Karpat'la ilgili olarak, Menderes-Özal-Erdoğan çizgisini İslam ekseninde tahlil etmesini bilimsel bir bakış açısıyla bağdaştıramayan görüşü ise; Türkiye'nin modernleşme tarihinde yoğun pozitivizmin etkisi dolayısıyla dinin

5 Nuray Sancar, Politik Akımlar \& İdeolojiler, Siyaset - Politika kategorilerinde eserler yazmış bir yazardır. Sancar'ın, Sıcak Haziran \& Sonrasındaki Mektup (2013) adlı kitabı adı geçen makaledeki argümanlarının daha geniş çerçevede ele alındığı bir eserdir. Esas itibarıyla Sancar'ın Karpat hakkındaki görüş ve söylemleri bu dönemde Türkiye'de yaşanılan değişim karşısında durduğu politik mevzi etrafında şekillenmiştir.

6 Nuray Sancar, “35 Y1l Sonra Gelen ün: Kemal Karpat Yeni Osmanlıcılı̆̆ın İdeolojik Bir Desteği”, Özgürlük Dünyasl, S.209 (Eylül 2009).

7 Nuray Sancar, “35 Yıl Sonra Gelen ün: Kemal Karpat Yeni Osmanlıcılığın İdeolojik Bir Desteği”, s. 2. 
(İslam'ın) dip akıntısı rolünü görmemekle ilgili bir duruma karş1lık gelir ${ }^{8}$ Şerif Mardin'in bu konudaki önemli saptamasında olduğu gibi İslam, her şeye rağmen Türkiye'nin toplumsal değişiminde temel belirleyicilerden biri olmuştur'. Sosyolojik açıdan bakıldığında yazarın bahsettiği söz konusu çizgideki temel dinamik de budur. Din konusu, pozitivist bilim zihniyeti dolayısıyla Türk akademiasının ilgisi dışında kalan, fakat Türk modernleşmesinin anlaşılmasında en önemli anahtar konulardan biridir.

Bunun dışında yazarın makalede belirttiği gibi Karpat'ın tarihle ilgisini, olmuş-bitmiş olayları anlamaya indirgeme beklentisindeki görüşü ise yazarın tarih bilimiyle ilgili sorunlu yaklaşımını yansıtmaktadır. Yazara göre Karpat'ın tarihe olan ilgisinde, tarih bilgisiyle bugünün nasıl açıklanacağı şeklindeki yaklaşımının bir kusur olarak görülmesi ayrı bir yanılgıdır. Zira Karpat'ın yaptığı gibi tarihin anlamı ve amacı tam da budur. Tarih, geçmişin bütün birikimine dayanarak bugünü anlamak ve çözümlemek için vardır. Tüm bilimlerde olduğu gibi bu husus da tarihin pragmatik yönünü oluşturur. Tarih geçmişteki olayların salt spekülasyonundan ibaret bir bilim değildir.

Yazar, Karpat'ın Türkiye tarihinde önemli kırılmalara yol açan olaylar sırasındaki ideolojik keskinlik taşımayan tutumunu da eleştiri konusu yapmıştır. Bunlardan biri olan Karpat'ın, 4 Aralık 1945'teki Tan baskını sırasındaki tavrı ve 1960'larda Yön bildirisini eleştirmesi ama onlarla ilişkisinin olması konusunda yazarın partizanlığın eşiği olarak gördüğü durum olup ${ }^{10}$ bu husus; bu tür olaylar karşısında toplumbilimsel tarihçiliğin gerektirdiği soğukkanlı tutumun ve mesafeli yaklaşımın bir göstergesidir. Hilmi Ziya Ülken 'in, çağdaş Türk aydınının kronik zaafı olarak gördüğü toplumsal gerçeklik ile iç içe olmaktan sakınmayı gerektiren bir durumda Karpat da, Tanpınar'ın her zaman yaptığı gibi eşikte durmayı bu tür olaylarda bir yöntem olarak tercih etmek suretiyle hadiseleri daha soğukkanlı bir şekilde değerlendirmeye çalışmıştır.

Karpat'ın çalışmalarının yazar tarafindan Büyük Ortadoğu Projesi (BOP) çerçevesinde 1lımlı İslam'ın ideolojik argümanlarına indirgenmesi ise tarihin salt ideolojik

8 Ali Yaşar Sarıbay'a göre Türk modernleşmesindeki dar pozitivizmin etkisiyle din konusu uzun süre akademik ilginin dışında kalmış ve İslam'a modernitenin bir patolojisi olarak yaklaşılmıştır. Türkiye'de Sosyolojinin Yüz Yıllık Birikimi, Ed. Erkan Çav-Elif Süreyya Genç, İstanbul, Ketebe Yayınları, 2020, s. 103. Necdet Subaşı ise bu konuda aynı tespitten hareket ederek dinin kamusal alandan tasfiyesi sonucu sosyolojinin konusu olmaktan çıkarılması dolayısıyla akademik ilginin dışında kaldığını belirtmiştir. Necdet Subaşı, "Sosyal Bilimsel İlgide Din ve Gecikmiş Fark Edilişler" Türkiye'de Sosyolojinin Yüz Yıllık Birikimi, Ed. Erkan Çav-Elif Süreyya Genç, İstanbul, Ketebe Yayınları, 2020, s.486. Bunun sonucunda Türkiye'deki sosyal bilimcilerin dinin ne olduğu konusunda cesaretle üzerine gidemediği bir süreçte Şerif Mardin ve Sabri Ülgener'den sonra Karpat da bu konuya tarihsel sosyolojik açıdan yaklaşarak fark oluşturan entelektüeller arasında yer almıştır.

9 Şerif Mardin, Din ve İdeoloji, İstanbul, İletişim Yayınları, 2007, s.102.

10 Nuray Sancar, “35 Y1l Sonra Gelen ün: Kemal Karpat Yeni Osmanlıcılığın İdeolojik Bir Desteği”, s, 3. 
açıdan ele alınmasına ve yorumlanmasına bir örnektir. Karpat, imparatorluk coğrafyasında ekonomiden toplumsal yapıya, düşünceden kültürel hayata uzanan çok geniş bir spektrumda yaşanılan değişimi bir modernleşme tarihçisi olarak incelemeye çalışmıştır. Bütün çalışmalarından da anlaşılabileceği gibi Karpat, bugün gelinen noktada söz konusu coğrafyada tasvip görmeyen 1lımlı İslam'dan başka Yeni Osmanlıcılık gibi bir anakronizmi en iyi görenlerden biridir. Tarihsel bir olgu olan modernleşme sürecinde başta Türkiye olmak üzere, Balkanlardan Ortadoğu'ya bu alanda yaşanılan sorunların aşılması konusunda potansiyel imkânların ortaya çıkarılmasına dönük çabalar, Karpat'ın çalışmalarının temelini oluşturur. Dolayısıyla Karpat'ın her biri yoğun emek ürünü olan çalışmalarının öncelikle bu açıdan ele alınması gerekir. Şayet Karpat, Daron Acemoğlu gibi Ortadoğu'da yaşanılan sorunların tümünü Osmanlı geçmişine endeksleyen indirgemeci bir yaklaşımı benimsemiş olsaydı muhtemelen bu şekilde bir eleştiriyle karşılaşmış olmayacaktı ${ }^{11}$.

Yazar, Karpat'1n bilimsel yöntemi konusunda Karl Marx’tan Max Weber'e kadar uzanan bir çizginin eklektik yanlarıyla ilgili bir eleştiri getirmiştir ${ }^{12}$. Bu husus 1930'larda Fernand Braudel ve arkadaşlarıyla başlayan Annales Okulu'nun bir yansıması olup, Karpat'ın çalışmalarında toplumbilimsel tarihçiliğin gerektirdiği sıkça görülen bir durumdur. Yöntem konusunda (teleolojik olmamak kaydıyla) çok kültürlülük ve demokrasi, Karpat' in temel perspektifidir ki bu husus tarihe bakış konusunda tartışılabilir.

Yazar, Karpat'ın İslam'ın Siyasallaşması adlı eserindeki tezleriyle ilgili olarak, Osmanlı Devleti'nde 19. yüzyılda görülen yapısal değişimin kökenleri konusunda onun, Marksist tarihçiliğin gerektirdiği yöntemi tutarlı bir şekilde takip etmemesinin üzerinde durmuştur. Bu husus ise Türkiye'de Fuat Köprülü ve Ömer Lütfi Barkan ile başlayıp, Kemal Tahir, Halil İnalcık ve Mehmet Genç'e kadar uzanan aydın grubu içinde, Marksist tarihçiliğin bir uzantısı olan ATÜT'çü (Asya Tipi Üretim Tarzı) yaklaşımların Türkiye'nin tarihsel gerçekliğini açıklamadaki yetersizliği ile ilgili bir durumdur. Yazar, artık günümüz Türkiye tarihçiliğinde yetersizliği dolayısıyla geçersizliği kabul edilmiş olan ATÜT'çü yaklaşımlar konusunda hâlâ iyimser görünmektedir. 1960'larda Osmanlı tarihine ciddi bir şekilde ilgiyi arttıran ATÜT'çü değerlendirmeler, Karpat'ın ve diğer modern tarihçilerin gündeminden düşmüştür.

11 Bu konuda Daron Acemoğlu'nun görüşlerinin kuramdan çok bir entelektüel fantazi değeri taşıdığıyla ilgili Şükrü Hanioğlu'nun makalesi bir örnek gösterilebilir. M. Şükrü Hanioğlu, "Ortadoğu'daki Sorunların Suçlusu Bulundu; Rahat Olabiliriz”, Sabah, 31 Ağustos 2014, s.3.

12 M. Şükrü Hanioğlu, “Ortadoğu'daki Sorunların Suçlusu Bulundu; Rahat Olabiliriz”, Sabah, 31 Ağustos 2014. s.3. 
Yazarın, Karpat'ın İslam'ın Siyasallaşması kitabında yer alan ve Sened-i İttifak'la başlayan yeni orta sınıf oluşumuna ilişkin Marksist sınıf tanımlaması yerine "elit"ler tabirini kullanmasına ilişkin getirdiği eleştiri ise ${ }^{13}$ yukarıdaki paragrafta kısaca değinilen; Osmanlı Devleti'nin yapısal farklılıkları dolayısıyla Avrupa feodalizmi gibi sınıfsal bir bakış açısıyla ele alınamamasıyla ilgili bir durumdur. Klasik Türk devlet geleneğinde olduğu gibi Osmanlı toplumunda Batı tarzı sınıfsal farklılıklara karşılık yönetici (askeri) ve yönetilenler (reaya) şeklinde ikili bir yapı söz konusudur. Yönetici sınıf ise Osmanlı sistemine özgü devşirme sisteminden gelen ve meritokrasi adı verilen bir yapıya dayanır. Sonraki dönemlerde elit zümre olarak adlandırılan bu grup ile halk arasında modernleşme ile birlikte yapısal değişim boyutunda sorunlar ortaya çıkmıştır. Her ne kadar bu mücadelede, 19. yüzyılda mülkiyet ilişkilerinin değişmeye başlaması sonucu ortaya çıkan yeni ideolojik yönelimlerin sınırlı ölçekte payı görülüyor olsa da bu durum bütünüyle bu olguyla açılanamaz. Mücadelenin temelinde, Karpat'ın da belirtiği gibi modern eğitim sisteminin yeni orta sınıfların ideolojik eğilimini tanımlamakta ve siyasetle ilgilenmelerini teşvik etmekte oynadığı hayati rolün altını çizmek gerekirir ${ }^{14}$. Toplumda dikey hareketliliğe de katkıda bulunan modern eğitimin bu işlevi, yönetici elitlerin bulundukları konum/durum hakkında önce aydınlara ve sonrasında halka sorgulayıcı bilinç kazandırmıştır. Dolayısıyla II. Abdülhamid'in (1876-1909) öncülük ettiği bu eğitim hamlesi nereden bakılırsa bakılsın ilerici bir harekettir. Karpat'a göre II. Abdülhamid'in saltanatı döneminde yapılan 1slahat, İslam hukuk düzeninden radikal bir şekilde ayrılmakla birlikte, Batı'nın ne örnek ne de teşvik edici hiçbir rol oynamadığı tam anlamıyla İslami bir icraattı ${ }^{15}$. Böylesi yapısal değişime imkân veren din anlayışı dolayısıyla (Mecelle örneğinde olduğu gibi) Karpat tarafından kabul edilen İslam'ın modernleşmeye ve yenikliklere açık bir din olduğu görüşü makale yazarı tarafindan temel eleştiri konularından biri sayılmıştır. Bir bütün olarak bakıldığında yazar tarafından bu dönemde yapılan modernleşme hamlelerinin çığır açıp neredeyse Cumhuriyet'e giden yolun açılmasıyla ilgili bir başka eleştirisi ise farklı bir değerlendirmeyi gerektirmektedir. Zira sonuç tam da yazarın eleştirdiği durumda olduğu gibidir. Karpat bu konuyu irdelediği bir başka makalesinde; II. Abdülhamid'in, İslam'ın büyük bir medeniyet yarattığını ve dogmatizmi yenip gerçek kimliğini ve öz saygısını kazandığında ilerleme kaydedeceğine inanan dindar bir Müslüman olduğunu belirterek makale yazarı olarak Osmanlı Devleti'ndeki gerçek modernleşmenin Abdülhamid döneminde başladı̆̆ı ve modern Türkiye'nin temellerinin yine bu dönemde atıldığı konusunda en ufak bir

13 M. Şükrü Hanioğlu, “Ortadoğu'daki Sorunların Suçlusu Bulundu; Rahat Olabiliriz”, Sabah, 31 Ağustos 2014, s.3.

14 Kemal H. Karpat, İslam ’n Siyasallaşması, 4. Bask1, İstanbul, İstanbul Bilgi Üniversitesi Yayınları, 2010, s. 178-179.

15 Kemal H. Karpat, İslam 'ın Siyasallaşması..., s. 209. 
şüphesinin olmadığını ifade etmiştir ${ }^{16}$. Türkiye tarihini, kültürünü gerçek manada anlamak ve anlatmak için bu topluma içeriden bakarak kendi bünyesi içindeki mevcut sosyal, ekonomik, kültürel güçlerin baskısı ile nasıl geliştiğini ve değiştiğini anlamak ve anlatmak gerektiğini belirten Karpat, yabancı ülkede gelişmiş, geliştirilmiş teorilerin kalıplarına Türk toplumunu sıkıştırmaya çalışmanın suni neticeler vereceğini belirtmiştir. Karpat bu meyanda ATÜT'çü yaklaşımların da bu yüzden sönük kaldığını ifade etmiştir. ${ }^{17} \mathrm{Bu}$ konuda Karpat'la benzer görüşleri paylaşan Norman Stone'nun da dediği gibi bu açıdan II. Abdülhamid modern Türkiye'nin babası sayılır.

Bir başka husus olan İslamcılık konusunda kökenleri yine bu döneme kadar uzanan demokratik/1lımlı/dünyevi İslam politikalarında ise konjonktürel dalgalanmalar yaşanmış olmakla birlikte sonuç itibarıyla yazarı haklı çıkaracak gelişmeler mevcuttur. Yazarın Abdülhamid İslamcılığını da kapsayan ve Cumhuriyet devrinde Soğuk Savaş döneminden başlayarak günümüze kadar olan dönemdeki bu tür arayışlar konusunda (Abdülhamid dönemi hariç) haklılık payı bulunmaktadır. Abdülhamid dönemindeki İslamcılığı ortaya çıkaran dinamiklerle, Soğuk Savaş ve sonrasındaki İslamcılı̆̆ın dinamikleri arasında önemli farklar bulunmaktadır. Soğuk Savaş döneminde Amerika Birleşik Devletleri’nin, komünizmin yayılmasını önlemek amacıyla geliştirdiği Yeşil Kuşak Projesiyle, Türkiye'yi de içine alan Ilımlı İslam politikası bir vakıadır. Ancak yazar, bunların hepsini aynı potada değerlendirerek toptancı bir yaklaşım göstermektedir. Dolayısıyla yazarın eleştirilerindeki haklılık payını teslim ederek dönemsel farklılıkların göz önüne alınması gerekir. Karpat'ın bu dönemlerle ilgili çalışmalarına 1lımlı İslam'a tarihsel meşruiyet kazandırma işlevi yüklemek, bu tür bakış içinde bulunanları analitik ve bütüncül değerlendirme konusunda yanlış sonuçlara götürebilir. Dahası bu tür değerlendirmeler aşırı işlevselci ve teleolojik malûliyetler içerir.

Karpat, Osmanlı'dan Günümüze Elitler ve Din kitabında yer alan "Siyasal Katılım ve Elitlerin Bileşimindeki Değişmeler" adlı makalesinde Abdülhamid'in yeni dönemde yapılacak reformlarla ilgili çekindiği geleneksel dinsel elitler zümresini oluşturan yüksek rütbeli ulema, meşihat ve kazaskerlik karşısında orta rütbeli ulemayı, taşra eşrafinı ve popüler tarikatları desteklediğini belirtmiştir. Abdülhamid, bu "popülist" dinsel devrimi kendi mutlak iktidarını sağlamlaştırmak amacıyla yürürlüğe sokarken istemeden yerleşik İslam'ın marjinalleşmesine neden olmuştur ${ }^{18}$. Sancar'1n, buradaki “istemeden”

16 Kemal H. Karpat, Osmanlı'dan Günümüze Elitler ve Din, İstanbul, Timaş Yayınları, 2009, s. 256.

17 Kemal H. Karpat, "Bir Sosyal Bilimcinin Tecrübesi”, Türkiye’de Sosyolojinin Yüz Yıllık Birikimi, Ed. Erkan Çav-Elif Süreyya Genç, İstanbul, Ketebe Yayınları, 2020, s. 55.

18 Kemal Karpat, Osmanlı'dan Günümüze..., s. 166. 
şeklinde bir ifadeye takılarak buradan hareketle Karpat'ın, İslam 'ın Siyasallaşması kitabındaki üslubunu baş aşağı bakmak şeklinde nitelemesi ise toptancı bir bakış açısının bir başka örneği teşkil eder. Zira söz konusu ifadenin "yanlışlı̆̆ı" bir yana, böyle olsa bile bunu mihenk taşı yaparak Karpat'ın elli yıllık çalışmasının ürünü olan eseri baş aşağı bir üslup şeklinde değerlendirmek, eserin içerdiği analitik çözümlemeleri göz ard1 etmek demektir. Dahası bu husus, yukarıda da belirtildiği gibi Karpat'ın ana akım tarihçiliğin dışında kalarak toplumbilimsel tarihçiliğin gerektirdiği yaklaşım ve yöntemleri kullanarak bütüncül değerlendirmelere ulaşmış olmasıyla ilgilidir. Dolayısıyla eleştiri konusunda bu hususun da göz önünde bulundurulması gerekir.

Yazarın, Karpat'ın temel kavramı olarak gördüğ̈̈ “süreklilik” konusunda (Türkiye Cumhuriyeti Osmanlı İmparatorluğu'nun kesintisiz bir devamıdır) şeklindeki eleştirisi ise tarihsel durum ve tarihçilik açısından son derece sorunludur. Kesintisiz ifadesi makale yazarının zorlamasıyla eklemlenmiş olmakla beraber tarihsel durum açısından konu bütünüyle böyledir denilebilir. Osmanlı'dan Cumhuriyet'e geçiş süreci ve Cumhuriyet tarihine dair ideolojik yaklaşımlar dışında diğer kapsamlı çözümlemelerden gün geçtikçe ortaya çıkan sonuç bu şekildedir ${ }^{19}$. Dahası tarihsel süreklilik konusunda Tanpınar'ın Beş Şehir adlı eseri bu konuda yeterince fikir vermektedir. Yazarın bir diğer eleştirisini oluşturan Karpat'ın Cumhuriyet elitlerinin siyasi başarısı konusunda, İslam dinini hesaba katmayanlar karşısında bu faktörü göz önünde bulunduranların daha başar1lı olduğuna ilişkin görüşleri ise teleolojik değil, olgusal bir durumdur.

Yazar'ın, Karpat'taki süreklilik ve değişim konusunda sınıfsal perspektiften yoksunluk şeklindeki eleştirisini ise Karpat'ın başlangıçtan beri Marksist anlamda sınıf kavramına Osmanlı devleti açısından yer vermeyişinde aramak gerekir. Karpat bunun yerine Türkiye sosyolojisinin geleneksel bir kategorisi olan cemaat ve tarikatlar içinde Nakşibendiliğin modernleşme süreciyle birlikte dinamik yapıya evrilmesinden hareket ederek genel olarak İslam dininin bu süreçteki itici güç olma rolünü incelemiştir. Makale yazarının temel eleştirilerinden biri olan İslam dininin modernleşmedeki rolü, Karpat'ın da belirttiği gibi Türk modernleşmesinde yaşanılan değişimin iki ana belirleyicisinden biridir. Karpat'ın, “Bir gün bu Nakşibendi şeyhlerinin birçoğu Müslüman devrimci ve

19 Türk modernleşmesinde süreklilik ve radikal kopuş tezleriyle ilgili iki önemli paradigma söz konusudur. Bernard Lewis, Niyazi Berkes, Tarık Zafer Tunaya ve Feroz Ahmad gibi isimlerin başını çektiği ve teleolojik, işlevselci, oryantalist, pozitivist, indirgemeci ve tek boyutlu zaaf yanları bulunan çatışmacı paradigma karşısında; kapsayıcı özellikleri ile bu zafiyetlerden uzak ve tarihsel-sosyolojik yaklaşımı esas alan bir de intibak paradigması mevcuttur. Şerif Mardin, Roderic H. Davison, Eric Jan Zürcher, Elizabeth Özdalga, Şükrü Hanioğlu, İsmail Kara gibi isimlerin yer aldığı bu paradigmada Karpat da bu grup arasında yer alır. Nurullah Ardıç, "Türk Sekülerleşmesi İncelemelerinde Paradigma Değişimine Doğru”, Türkiye Araştırmaları Literatür Dergisi, S. 11, (2008), s. 69-74. 
yenilikçilerin panteonunda yerini alacaklardır"20 ifadesi, ana belirleyicinin bir diğeri olan orta sınıf üzerinde birincisinin etkisini gösterir. Karpat'a göre Nakşibendi’ye, yeni orta sınıfın kültürel profilini temsil ederken; Ali Suavi gibi İslamcı-reformist-devrimci aydınlar da bu sınıfın ideolojik, politik eylemci yanını temsil ediyorlardı. Bununla beraber makale yazarının, 19. yüzyılda Osmanlı Devleti’nde yaşanılan değişimin Nakşibendilik marifeti olarak görülemeyeceği şeklindeki değerlendirmesi yerinde bir tespittir. Ancak Karpat'ın böyle bir iddiası yoktur. Karpat, modernleşmenin toplumsal, siyasal, iktisadi, düşünsel (ideolojik) sebeplerinin dışsal etkileri konusunda son derece hassastır. Karpat, Nakşibendiliği Osmanlı Devleti'nde o dönemde farklı bileşenlerin bir araya gelmesiyle ortaya çıkan yeni bir yapısal değişim dinamiğini açıklamak amacıyla ele almıştır. Bununla beraber Karpat'a göre; 19. yüzyılın başında mülkiyet bilincine sahip ayanların, 1850'lerden sonra da onların ardılı olarak büyüklük ve nüfuz açısından hızla gelişen mülk sahibi grupların ortaya çıkışı, Osmanlı Devleti'nde ve nihayet Türkiye'de temsili yönetimin kurulmasının dayanağını oluşturan temel toplumsal gelişmedir $^{21}$ ki bu husus, aynı zamanda süreklilik konusunun bir başka göstergesidir.

Yazar'ın, Karpat'ın Türkiye tarihinin kırılma noktalarını oluşturan 27 Mayıs 1960, 12 Mart 1971 ve 12 Eylül 1980 darbeleriyle ilgili görüşlerine dair getirdiği bazı eleştirileri ise yerinde görünmektedir. Karpat bu darbeler konusunda terminolojik bir duyarlılık gösterememektedir. Özellikle 1980 darbesinin askeri müdahale şeklinde adlandırılması ve bu darbede halk vurgusunun öne çıkarılması konuyla ilgili kaçamak bir yaklaşımı yansıtmaktadır. Darbe sonrasında Kenan Evren'in yaptığı meydan konuşmalarında halk desteğinin, darbenin dinamiği gibi gösterilmesi bunun bir örneğidir ${ }^{22}$. Bunun dışında yazarın 12 Eylül'ün ekonomi politiği ile ilgili eleştirileri ise kendi bakış açısından tutar11 görünmektedir.

\section{Sonuç yerine}

Makale yazarının Karpat'la ilgili temel eleştiri konularından biri de onun, Türkiye'nin 21. yüzyılda yaşadığı büyük değişimi Yeni Osmanlıcılık şeklinde değerlendirmesidir. Karpat'1n “sivil, politik, sosyal ve kültürel devrim” olarak gördüğü yeni dönemi, yazar ABD’nin bölgedeki hegemonyasını güçlendirmek için uyguladı̆̆ı politik eylemlerin destekçisi olabilecek bir yapı olarak nitelemiştir. Oysa bu süreci, dönem konjonktüründe iki ülkenin kesişen pragmatik çıkarları doğrultusunda yaşanılan

20 Kemal Karpat, Osmanlı'dan Günümüze...,s. 193.

21 Kemal Karpat, Osmanlı'dan Günümüze..., s. 132.

22 Kemal H. Karpat, Dă̆ı Delen Irmak, Ankara, İmge Kitabevi, 2008, s. 456. 
gelişmeler ekseninde değerlendirmek, bu güne göre geçerliliğini yitirmiştir. Uzunca bir süredir Türkiye'nin ABD ile yaşadığı gerilim bunun bir göstergesidir. Bir Soğuk Savaş dönemi kurgusu olan "Ilımlı İslam" ve "dünyevi İslam" projeleri bugün çökmüştür. Bazı marjinal çevrelerin romantik bir hülyası olan Yeni Osmanlıcılık düşüncesi de tam bir anakronizmdir. $\mathrm{Bu}$ hususu en iyi bilen ve öyle değerlendiren kişilerden biri de Karpat'tır.

Yazarın da belirtiği gibi bir tarihçi, zaten önünde duran olmuş bitmiş olgular yığınından tutarlı sonuçlara ulaşarak tarih yazmak zorundadır. Bu birbirine anlamlı bir biçimde bağlanmayı bekleyen olgular yığınından başlayarak bugüne kadar çizdiği çizgi, tarihçiyi eninde sonunda güncellik içinde bir tutum almaya zorlar. Ancak Karpat'ın karşı karşıya kaldığı durum, zorlama yorumlarla ve makul olmayan yaklaşımlarla romantik bir ideolojinin etkisi altında kalıp bu ideolojin manipülasyonlarına tabi olmak değildir. Karpat, olgulardan hareketle ve sosyolojik bir yaklaşımla ve güçlü bir perspektif zenginliği içinde Türk modernleşmesi gibi karmaşık bir konuyu çözümlemeye çalışmıştır Karpat tam da bunu yapmıştır. Tarihçilik konusunda Karpat'a isnat edilebilecek teleolojik boyut şudur: Karpat, 20. yüzyılın ikinci yarısıyla birlikte Amerikan bilimi etrafında sosyal bilimlerce benimsenen modernleşme paradigmasının Türkiye'deki öncülerinden biridir. 1959-1964 yılları arasında Türkiye tarihini bu açıdan ele alan altı önemli çalışmadan dördünün Princeton Üniversitesi Yayınevi tarafından yapılması bir tesadüf değil$\operatorname{dir}^{23}$. Bedri Gencer'in de belirtiği gibi bu çalışmalar komünist tehlikeye karşı Batılı kapitalist sisteme entegrasyon bahanesiyle modernleşme projesinin, sözde Üçüncü Dünya ülkelerine nasıl dayatıldığını ortaya koyar. Bu çalışmaların ana illeti İslami imparatorluktan seküler cumhuriyete doğru ilerleyen teleolojik bir vizyona dayanmalardir ${ }^{24}$. Karpat da bu paradigma içinde yer alarak modernite içinde Türkiye tarihinin modernleşme serüvenini olgusal bir bakış açısıyla ele almış ve bunu çoğu tarihçinin yapamadığ1 ölçekte objektif bir anlayışla gerçekleştirmiştir. Dolayısıyla Karpat'ın tarihçiliğini ve geldiği noktayı Yeni Osmanlıcılığın ideolojik temsilciliğine indirgemek, en naif tabiriyle söylemek gerekirse büyük bir haksızlık olacaktır. Bu türden çalışmaların daha sağlık11 ve nesnel değerlendirilebilmesi için modern tarihçiliğin gerektirdiği disiplinlerarası ve bütüncül bakış açılarına ihtiyaç vardır.

23 Bu çalışmalar sırasıyla; 1- Karpat, Kemal (1959), Turkey's Politics: The Transition to a Multi-Party System, Princeton: Princeton UP; 2- Lewis, Bernard (1961), The Emergence of Modern Turkey. New York: Oxford UP; 3- Mardin, Şerif ( 1962), The Genesis of the Young Ottoman Thought: A Study in the Modernisation of Turkish Political Ideas. Princeton: Princeton UP; 4-Davison, Roderic (1963), Reform in the Ottoman Empire 1856-1876. Princeton: Princeton UP; 5Berkes, Niyazi ( 1964), The Development of Secularism in Turkey. Montreal: Mc Gill University Press; 6- Ward, Robert E-Rustow, Dankwart A. (eds.) (1964), Poltical Modernisation in Japan and Turkey. Princeton: Princeton UP. 
Hakem Değerlendirmesi: Dış bağımsız.

Çıkar Çatışması: Yazar çıkar çatışması bildirmemiştir.

Finansal Destek: Yazar bu çalışma için finansal destek almadığını beyan etmiştir.

Peer-review: Externally peer-reviewed.

Conflict of Interest: The author has no conflict of interest to declare.

Grant Support: The author declared that this study has received no financial support.

\section{KAYNAKÇA}

\section{Araştırma Eserler}

Ardıç, Nurullah: "Türk Sekülerleşmesi İncelemelerinde Paradigma Değişimine Doğru”,

Türkiye Araştırmaları Literatür Dergisi, S. 11, 2008.

Belge, Murat: 'Osmanlı'da ve Rusya'da Aydınlar”, Türk Aydını ve Kimlik Sorunu, Yay.

Haz. Sabahattin Şen, İstanbul 1995.

Gencer, Bedri: Gelenekten Modernliğe Osmanl, İstanbul, Ketebe Yayınevi, 2019.

Karpat, Kemal H.: Dağı Delen Irmak, Ankara, İmge Kitabevi, 2008.

: İslam'ın Siyasallaşması, 4. Baskı, İstanbul, İstanbul Bilgi Üniversitesi

Yayınlar1, 2010.

:Osmanll'dan Günümüze Elitler ve Din, İstanbul, Timaş Yayınları, 2009.

: "Bir Sosyal Bilimcinin Tecrübesi”, Türkiye'de Sosyolojinin Yüz Ylllk

Birikimi, Ed. Erkan Çav-Elif Süreyya Genç, İstanbul, Ketebe Yayınları, 2020. ss.53-55.

Mardin, Şerif: Din ve İdeoloji, İstanbul, İletişim Yayınları, 2007.

Sancar, Nuray: "35 Y1l Sonra Gelen ün: Kemal Karpat Yeni Osmanlıcılı̆̆ın İdeolojik Bir

Desteği”, Özgürlük Dünyası, S.209, Eylül 2009.

Sarıbay, Ali Yaşar: Türkiye'de Sosyolojinin Yüz Yıllık Birikimi, Ed. Erkan Çam-Elif

Süreyya Genç, İstanbul, Ketebe Yayınları, 2020.

Subaş1, Necdet: "Sosyal Bilimsel İlgide Din ve Gecikmiş Fark Edilişler" Türkiye'de

Sosyolojinin Yüz Ylllık Birikimi, Ed. Erkan Çav-Elif Süreyya Genç, İstanbul, Ketebe

Yayınlar1, 2020.

Sunar, Lütfi: "Karpat Neden Göz Ardı Edildi? Modernleşmeye Dair Farklı Bir Bakış", Tezkire, S. 64. Nisan-Mayıs-Haziran 2018.

Yetim, Fahri: “Türkiye'nin Modernleşme Tarihçisi Kemal H. Karpat”, Yaşayan Türk

Tarihçileri, Ed. Ahmet Şimşek, Ankara, Pegem Akademi, 2018, ss. 135-147. 